\title{
HEAD-SHIELD BROOCHES OF THE ROMAN IRON AGE FROM THE TARAND CEMETERIES OF THE EASTERN BALTIC
}

\author{
MAARJA LILLAK, ${ }^{1 *}$ MARCUS A. ROXBURGH ${ }^{2}$
}

\author{
${ }^{1}$ Independent researcher \\ ${ }^{2}$ Department of Archaeology, Institute of History and Archaeology, University of Tartu, Jakobi 2, Tartu, Estonia
}

Keywords

head-shield brooches, tarand cemeteries, eastern Baltic, Roman Iron Age, XRF

\begin{abstract}
This study is dedicated to the head-shield brooches from the tarand cemetery area in Estonia, Latvia and lands west of the Izhora plateau. Its aim is to better understand their development through a combined typological, compositional and chronological analysis and explore their social role in the identity politics of the people wearing them. The compositional evaluation was supported with portable X-ray florescence spectrometry (XRF), to improve our understanding of the metal choices made by their ancient craftsmen.

The typological study suggests that one of the earliest brooches found in the tarand cemetery area belongs to the Almgren 100 brooches, most of which have a semi-circular shield on the front part of the bow, a multiple-piece spring, and a triangular foot. The evidence suggests that they emerged in the 2nd century. Subsequently, a local form developed in the northeast part of the tarand cemetery area towards the end of the century. This local type has a squared-off foot, a multiple-piece spring construction, and a short semi-circular head-shield. Many were also tinned, meaning their colour was deliberately changed to a shiny silvery-white. During the 3rd century, a further group of locally produced head-shield brooches also emerged. They have a hinged mechanism, a knob, and a decorative rib at the end of the foot.

These local brooches likely represented a regional style and aesthetic. They could have played a visual role in connecting the wearer to their affiliated group, or played a part in a differing social role within the society from which they came.
\end{abstract}

\section{Introduction}

The head-shield brooch forms found in the tarand cemetery area are primarily recognised by their distinctive 'shield' shape on the front part of their bow. This shape subsequently associates them with the northern, Almgren group V (1897, p. 48). They date from the Roman Iron Age, and are among the earliest types of brooches recovered from the areas where tarand cemeteries are commonly located (Lang 2007, p. 191). Many of the earliest examples of this brooch type are also found on the southeast shore of the Baltic Sea (Lang 2007, p. 206). Contact with the inhabitants of this distant shoreline (now modern-day Lithuania, the Kaliningrad oblast and eastern Poland) is considered to have greatly influenced the lives of the people who created and used these tarand cemeteries (Schmiedehelm 1923; 1931; Moora 1938, p. 609; Lang 2007, p. 206; Olli 2019b, pp. 84-86). This contact is particularly important in attempting to understand more about those buried in the tarand cemeteries during this early period. The northern and eastern coastal areas of the Baltic Sea, our research area, were in frequent communication with quite distant regions during the Roman Iron Age, with many long-distance influences being evident in the archaeological record (Banytè-Rowell and BitnerWróblewska 2005, p. 116). The whole area is thought to have benefited from being connected to the ancient communication routes leading through the Barbaricum at this time (ibid.). At the beginning of the period, several new types of personal ornaments appeared, which were very

\footnotetext{
*Corresponding author. E-mail: maarjalillak@gmail.com
} 
similar across the whole eastern Baltic; however, local variations of some of these ornaments emerged over the following centuries (Moora 1938; Lang 2007, p. 206; Olli and Roxburgh 2018; Roxburgh and Olli 2019).

Most of the items recovered from the Roman Iron Age are found in tarand cemeteries. The distribution area for these cemeteries stretches across Estonia and north Latvia, and also includes lands west of the Izhora plateau in Russia, as well as the west and southwest coast of Finland (Salo 1968, p. 183; LA 1974, Fig. 37; Keskitalo 1979; Lang 2007, p. 191, Fig. 116; Yushkova 2016, p. 144, Fig. 1) (Fig. 1). These cemeteries are best described as above ground, monumental, communal, burial places, containing fragmented, commingled burials, where the bones and grave goods are intermixed (Olli 2019b, p. 13). Because complete burials are rare, especially within clearly stratifiable contexts, a precise chronology for the items recovered from them is difficult to establish (ibid., pp. 13-14, 44-45). The dates for most of the items are based on similar items found in the coastal area of Lithuania, the Kaliningrad oblast and Poland, where their chronology is better understood (Lang 2007, p. 206). The locally produced versions of some of these items also remain difficult to date, again due to the commingled nature of their find contexts. The earliest examples largely resemble those from the east Baltic area, and may well have been imports; therefore, locally produced versions should not be dated too far from these originals (Olli 2019b, p. 45). But then the earliest locally made brooches developed further over time, making their period of use more difficult to determine (ibid.). To better understand these brooches, their typological development has to be studied (e.g. their construction, decoration and alloy composition), and also compared to associated finds recovered from sealed find contexts (e.g. wealth deposits), especially in suggesting their circulation period (ibid.).

This study is the first paper solely dedicated to the headshield brooches recovered from the tarand cemetery area in Estonia, Latvia and lands west of the Izhora plateau. Its aim is to gain a better understanding of the development of these brooches, through a combined typological, compositional and chronological study. Various morphological aspects of their development will be compared both regionally and with similar developments elsewhere, to gain a better understanding of both their chronological development and the nature of contact between the people of the tarand cemeteries and those of other regions. Furthermore, an evaluation of the composition of these brooches using a non-destructive method, developed for portable X-ray florescence spectrometry (XRF), will improve our understanding of the metal choices made by these ancient craftsmen. The results present an updated typology for head-shield brooches found in the region. In conjunction with this, the results of a compositional study of the most commonly found types is also presented. From these results, a discussion then takes place surrounding their chronology and cultural meaning before the conclusions are drawn.

\section{A history of the typological research}

The typological study of north European head-shield brooches started within the wider study of Roman Iron Age brooches at the end of the 19th century. This is also when tarand cemeteries were first systematically excavated and published (i.e. Hausmann 1896). This early work allowed parallels to be drawn with Oscar Almgren's northern typology (1897), and the brooches found in the tarand cemeteries were subsequently classified according to it. Head-shield brooches were among the artefacts studied at this time, but no special publication was dedicated to them. Some decades later, Harri Moora studied the earliest head-shield brooches from Latvia (1938, pp. 65-76), then Artur Vassar wrote about those found in the Nurmsi tarand cemetery (central Estonia), and also gathered information about other head-shield brooches found in other parts of Estonia (Vassar 1943, pp. 63-66). Marta Schmiedehelm subsequently excavated many tarand cemeteries in northeast Estonia, and a lot of new information became available as a result, especially about the many types of items found in them, including these brooches (Schmiedehelm 1955). Silvia Laul studied artefacts from this period in southeast Estonia, but as these brooches are not so common in this area (2001, p. 97), little new knowledge was gained. Head-shield brooches found in Finland have been discussed alongside other material found from the Roman Iron Age, for example Ella Kivikoski (1973), Unto Salo (1968) and Oiva Keskitalo (1979). There are only a few head-shield brooches found in Finland, and they greatly resemble the ones found in Estonia, north Latvia and on the Izhora plateau.

In recent years, typological research, combined with the compositional study of Roman Iron Age brooches found in the tarand cemetery area, has emerged. In this way, eye brooches and disc brooches have been studied (Olli and Roxburgh 2018; Roxburgh and Olli 2019), revealing a cluster of certain brooch types in different regions. In addition, it was discovered that disc brooches in southeast Estonia and northern Latvia appear to have regularly received tinned surface treatments, while the northeast disc brooches do not (Olli and Roxburgh 2018, p. 49). The regional aspect of the distribution of cross-ribbed brooches found in southeast Estonia and north Latvia has also been discussed in a combined typological and network science approach (Olli 2019a) (Fig. 1). 


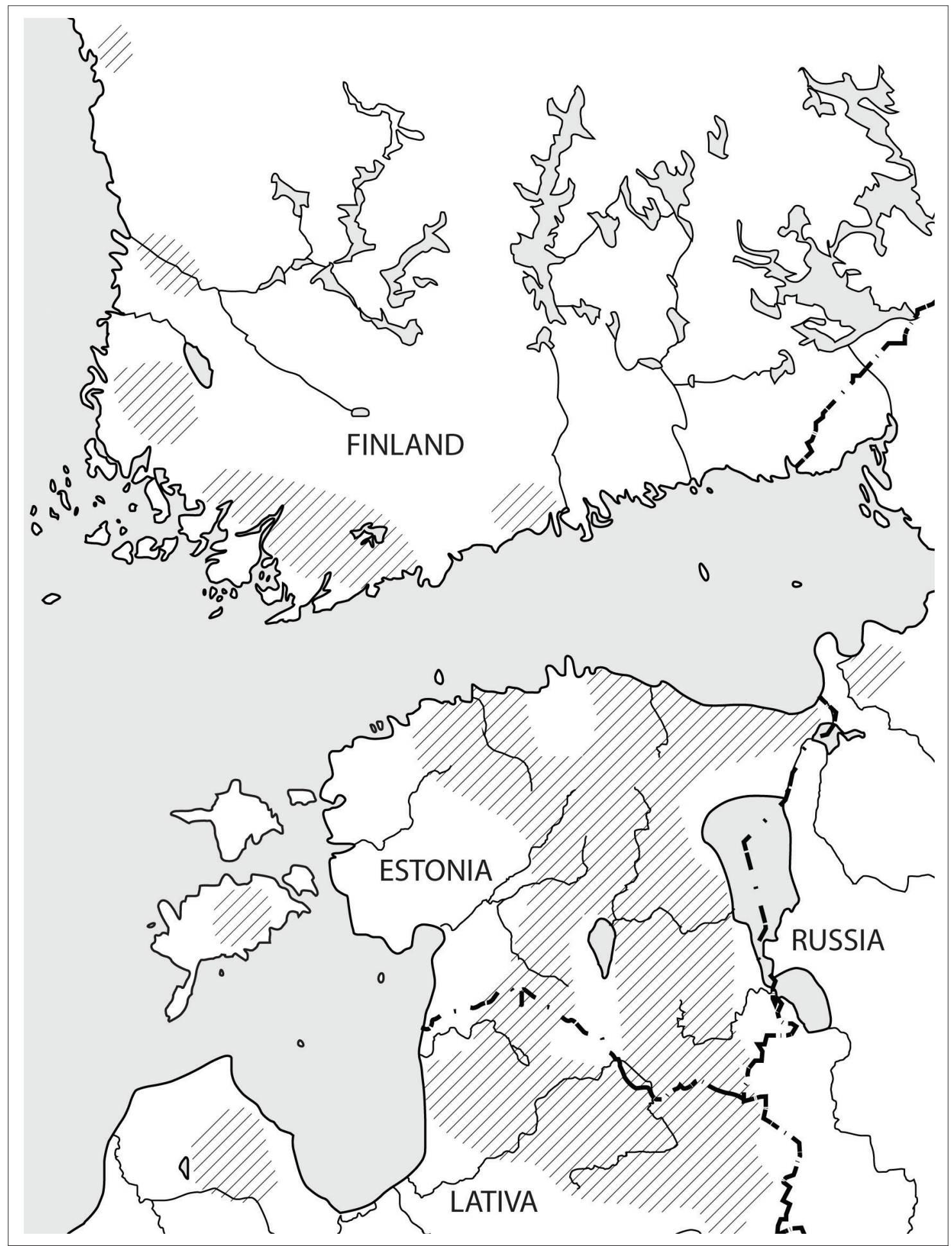

Figure 1. Tarand cemetery areas during the Roman Iron Age (after Laul 2001, p. 28 Fig. 3; Vasks 2001, p. 215, Fig. 157; Lang 2018, p. 175. Fig. 5.10).

The history of copper-alloy research

Scientific interest in the composition of ancient metallic objects has existed for over 200 years. Objects dating from the Roman Iron Age, and brooches in particular, have been a popular artefact group, particularly because around 140 have been recovered so far, and much effort has subsequently taken place to catalogue them and to cre- ate typological associations. One of the earliest attempts to use alloy composition to increase our knowledge of past societies was by Professor Friedemann Göbel at the University of Dorpat, now modern-day Tartu, where he collected chemical data from many Greek, Roman and Chinese museum objects, as well as many items recovered in the Baltic area from similar time periods (Göbel 1842). Since then, a large amount of work has been undertaken 
by many researchers in order to better understand the choice of production methods in the creation of these ancient objects. The compositional choices in the production of copper-alloy brooches (copper alloyed with tin, zinc or combinations of both, with or without added lead) allow us to study the complex relationship between typology and craft (Smythe 1938; Craddock 1988; Unglick 1991; Dungworth 1997, p. 902). A more commonly available, modern technique for the study of archaeological items is XRF. Whilst this technology has been around for decades, it was originally very large in size, making it a static piece of laboratory apparatus. But thanks to advances in miniaturisation, these devices have become increasingly portable, with many hand-sized models now being easily transportable to museums and archaeological excavations (Gigante et al. 2005; Shugar and Mass 2012). There are a number of traditional methods available that have traditionally required the destructive removal of a sample, usually by drilling or scraping to gain a measurement. But portable, easy to operate, hand-held devices (XRF) can also be used in a non-destructive manner, which is the approach adopted here. The problem with destructive sampling, taking a copper-alloy brooch as an example, is that the patina would have to be scraped off so that a fresh subsurface could be accessed for measuring. This kind of damage is quite opposed in modern conservation practices, which results in very few permissions being given by owners or museum curators. The non-destructive method using XRF avoids this problem, even though its use is limited to surface measurement. The X-rays can only penetrate to a fraction of a millimetre on copper-alloy artefacts. The implication for this is that the measurements are always taken on a surface that has been altered by the corrosion process. Past research has demonstrated that this corrosion process mainly involves the leeching out of copper (decuprification), and also, when present, zinc (dezincification), both of which contribute to the formation of an artefact's outer patina when buried in the soil for many hundreds of years (Robbiola et al. 1998, p. 2108; Chiavari et al. 2007). It is important to realise these limitations, and to ask the appropriate research questions. In this case, it requires the measurement of numerous objects that are typologically very similar. This is so that any similarities can be observed between basic compositional groups (e.g. Martinón-Torres et al. 2014; van Thienen and Lycke 2017). One additional aspect of its use as a surface analysis device is its ability to look for evidence of past surface treatments, such as tin or pewter coating, which may have been popular on some types of Roman-period brooches (Bayley and Butcher 2004, p. 43; Olli and Roxburgh 2018, pp. 54-59). It is also a technique that is evident in jewellery from the late 1 st to the mid-2nd century onwards found in Lithuania (Bliujienè 2013, p. 360).

\section{Head-shield brooches found in tarand cemetery areas}

Almgren placed brooch forms with a 'shield' on the front part of the bow exclusively within his Northern Europe group V (1897, pp. 48-53). However, there are clear morphological similarities with some brooch types found further away in the Roman Rhine provinces. The Germanic knee brooches with head-plate (Heeren and van der Feijst 2017, p. 136, group 51) found along the Roman frontier have semi-circular head-plates that appear during the first half of the 2nd century, and some variants also include foot knobs, a feature seen on some northern head-shield brooches (Fig. 2). The earliest examples of the multiplepiece spring construction seen on these brooches (Heeren and van der Feijst 2017, p. 13, Fig. 2.3, C7), date from the Earliest Roman Iron Age, but this construction remains uncommon in the Early Roman period, becoming popular again at the end of the 1st century, when it emerges again for use on Germanic knee and strong profiled brooches (Heeren and van der Feijst 2017, p. 12, groups 44 and 49). The construction became the most popular choice for most 2nd-century brooches in the Rhine provinces (Heeren and van der Feijst 2017, p. 12).

Around 140 head-shield brooches have been found so far in the tarand cemetery areas in Estonia, north Latvia and the Izhora plateau (Moora 1938, pp. 65-76; Vassar 1943, pp. 63-66; Laul 2001, p. 97; Yushkova 2016). Of these, 129 have subsequently been included in the typological part of this paper. Brooches with missing location information and those which were not accessible to the authors are not included (Appendix 1).

\section{Head-shield brooches with a triangular foot}

The earliest of the head-shield brooches recovered from the tarand cemetery area have a splayed triangular foot and a semi-circular head-shield (Figs. 3 and 4). They have a multiple-piece spring pin construction (there are two holes behind the shield, an upper one for the spiral cord, and a lower one for the axis) that is comparable to the Roman provincial construction mentioned above (Fig. 2).

Typologically speaking, head-shield brooches with a triangular foot are considered to be a local, Eastern Baltic form, belonging to Almgren group V, series 2, no. 100 (Almgren 1897, p. 51; Moora 1938, p. 70; Vassar 1943, p. 63; Nowakowski 2013, p. 136). Moora related the Estonian and Latvian specimens to ones found in Masuria and the Vistula delta area in northern Poland, and gives them similar dates (1938, p. 72). However, Almgren 100 brooches are also found in Lithuania (Michelbertas 1986, p. 115), but many of these brooches do not have a head-shield. 


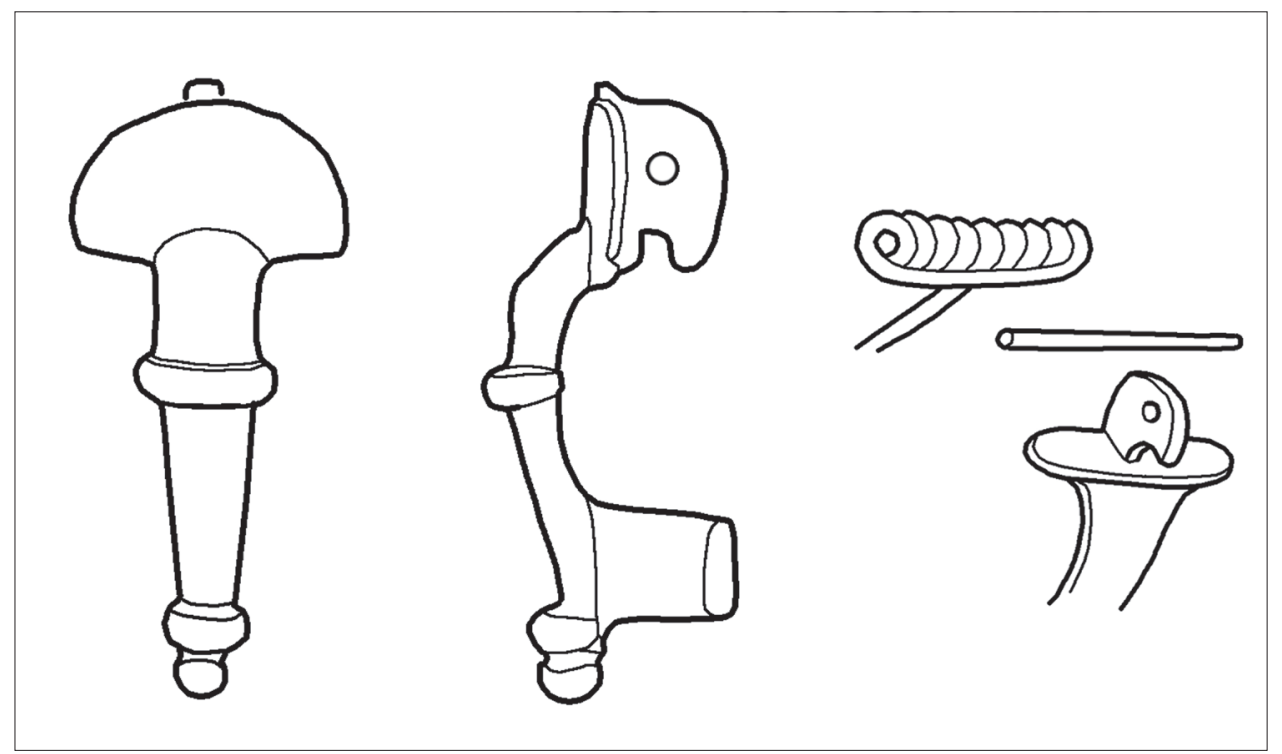

Figure 2. Germanic knee brooch type 51, and C7 multiple spring construction (after Heeren, van der Feijst 2017, p. 136, 51; p. 13, Fig. 2.3, C7).

These Almgren 100 brooches are mostly dated to the end of the 1st century to the middle of the 2 nd century, and some also up to the beginning of the 3rd century (B2 and B2/C1 periods respectively, see Nowakowski 2013, p. 136). Therefore, a similar date for the ones found in the tarand cemetery area can be proposed.

Although generally quite uniform in their construction and decorative elements, there is some variation in pin construction and decoration. Some, for example, have a hinge mechanism, which is formed by two lugs attached to the brooch, and each lug has a hole holding the axis (Heeren and van der Feijst, 2017, p. 13, Fig. 2.3, group $\mathrm{C} 12$ ). One specimen, which is bigger than the others and was found in a 3rd-century wealth deposit (Lang 1996, pp. $328,333)$, has a hinge mechanism in which the axis runs through a tube (tubular variant, see Heeren and van der Feijst, 2017, p. 13, Fig. 2.3, group C13). Some brooches found in the study area also have knobs decorating the bow and/or on the triangular foot. For example, a brooch found in the Slavēka cemetery in Latvia has knobs decorating the bow Catalogue ID-AI 1195: 103, (Fig. 4). Also, head-shield brooches with knobs at the end of their triangular foot have been found in Izhora plateau cemeteries (Jushkova 2011, Figs. 127 and 133). There is also one from Tõrma cemetery in northeast Estonia (Catalogue ID-AI 2496:39). These brooches, however, have a tubular-variant hinge construction, which could infer a later development stage. The use of knobs as a decorative element on Roman Period ornaments (including brooches) is usual for the tarand cemetery area. But this is not the case for headshield brooches. Parallels of 'knob' head-shield brooches with a triangular foot can be found in the southern areas of the Baltic Sea region (Szymański 2005, p. 21). Head- shield brooches with a triangular foot are found in all parts of the tarand cemetery area, but with the main concentration towards the northeast (Figs. 3 and 4).

\section{Local head-shield brooches}

It is thought that the craftsmen working in the northeastern part of the tarand cemetery area started to develop their own local versions of head-shield brooches during the 2nd century (Schmiedehelm 1955, p. 94). These local versions were probably inspired by the triangular foot types mentioned above, and can be divided into two groups. The groups have previously been identified by $\mathrm{H}$. Moora (1938, pp. 65-76) and A. Vassar (1943, pp. 63-66), but the authors of this article have revised them, compared them with newer data, and renamed the groups.

\section{Group A: Head-shield brooches with a squared-off foot}

The first group have a hollow faceted bow, a squared-off foot and a short, semi-circular head shield (Figs. 3 and 5). Most of them share the same multiple-piece spring construction as the earliest triangular foot ones. The shared spring construction is the connecting factor between the two, in addition to a head shield. Vassar connected these to Almgren 120 brooches (Vassar 1943, pp. 64-66), but the Almgren 120 brooches do not have a faceted bow.

The earliest brooches with a spring construction are dated to the end of the 2nd century (Vassar 1943, p. 65). Over time, they underwent some stylistic and constructional changes. The side facets became longer, and the end of 

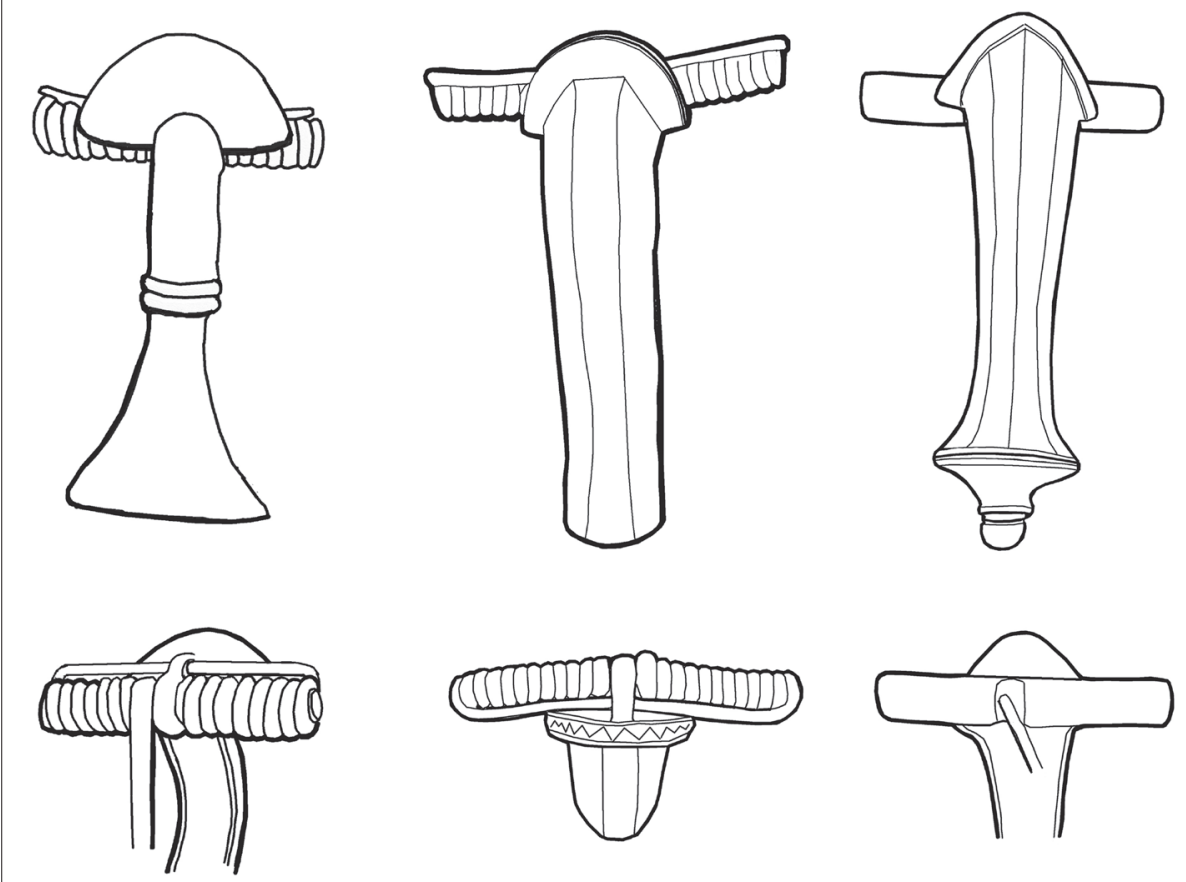

Figure 3. Head-shield brooches: triangular foot with spring construction (left); local group A with alternative view of the same spring construction (middle); local group B with hinge construction (right).

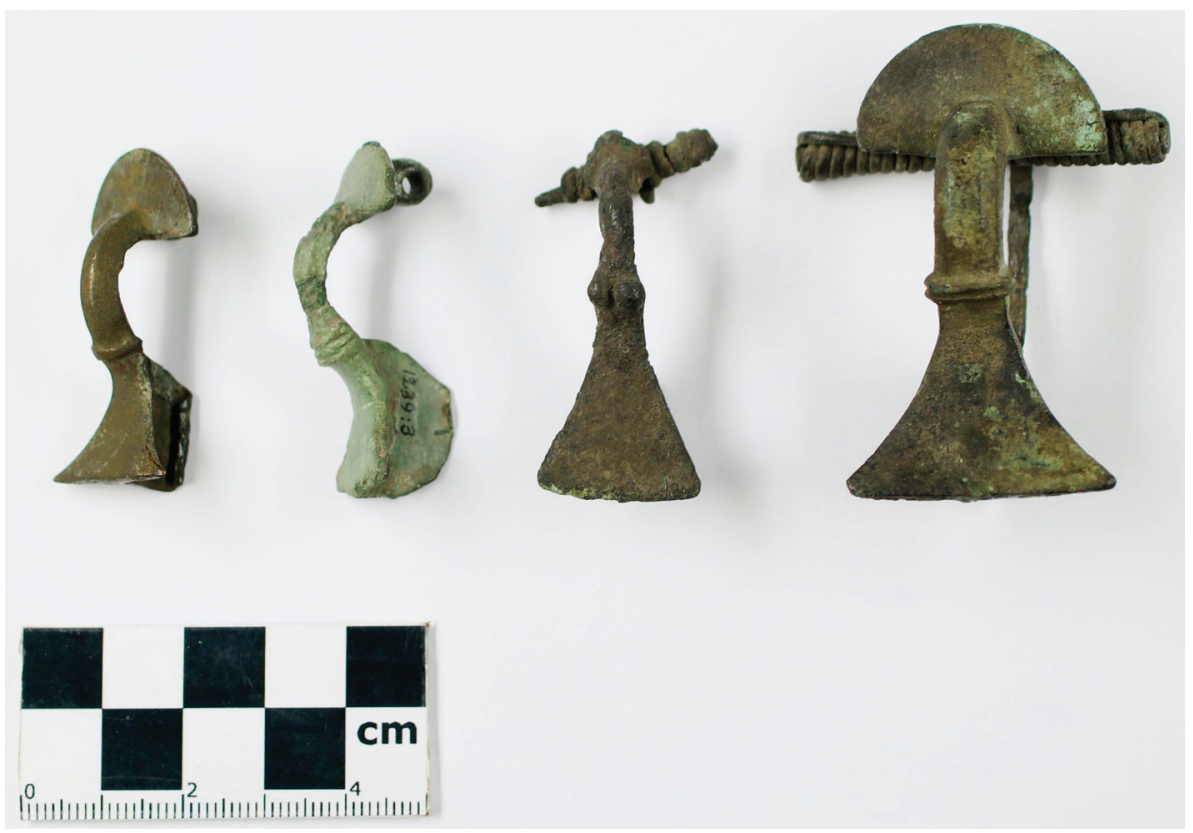

Figure 4. Head-shield brooches with a triangular foot (from left: AI 2011: 3, AI 1239: 3, AI 1195: 103, AI 1195: 95).

the bow became 'closed' (Vassar 1943, p. 64). Some of the brooches have a tubular variant of a hinge mechanism (Heeren and van der Feijst 2017, p. 13, Fig. 2.3, group C13) and are dated to the 3rd and 4th centuries (Vassar 1943, p. 65; Laul 2001, p. 97). The latter mechanism was also used on group four of the eye brooches of the Estoni- an series, which are dated broadly to between the 3rd and 6th centuries, and are thought to have been produced locally (Moora 1923; Roxburgh and Olli 2019, p. 607). From these observations, the head-shield brooches with a hinge mechanism can be considered a later, local development of the spring variants. 
Some brooches of this group are also decorated. This is mainly on the front of the shield, mostly with lines, but also with zigzags and dot patterns. The needle holder is sometimes decorated as well, with lines, crosses or zigzags. In two cases, lines also occur on the middle of the bow. Some brooches also have a small decorative knob at the end of the bow.

This group is largely found in the northeast part of the tarand cemetery area (for this see Fig. 9). The brooches with tubular-variant hinge mechanisms are concentrated in central and northeast Estonia.

\section{Group B: Head-shield brooches with} a foot knob

The second group of head-shield brooches are identified by the presence of a knob and a rib at the end of the foot (Figs. 3 and 6). These brooches were in use during the same period as the first group, but they emerge a bit later, and were probably in use for a longer time (Vassar 1943, p. 65). Their constructional and stylistic elements also support their later emergence. Most of the brooches in this group are quite large in comparison, they also have a hollow bow, a hinged pin (only a few have a multiple-piece spring construction) and a hollow head-shield, elements that refer to a later stage of typological development. Another identifiable feature of their late development is a decorative rib on the bow, just above the knob. Their development is similar to the development of Estonian eye brooches (third and fourth groups, see Moora 1923; Roxburgh and Olli 2019): the brooches increase in size, are hollow, are very finely crafted, and also have a hinge mechanism. The same is true for the 4 th-century crossribbed brooches of the south Estonian and north Latvian series, which are considered to be local to those areas (Laul 2001, pp. 103-108; Olli 2019a). The date of the headshield brooches of group B should also be similar: they emerge in the 3rd century, and continue in use during the 4th century (also see Schmiedehelm 1955, p. 94).

As was mentioned earlier, many head-shield brooches are finely crafted and also decorated. The shield in this group is sometimes decorated with lines, zigzags or dots. The same is also true for the foot and the rib before the foot. Another variation is that the shield can also be triangular. Schmiedehelm proposed that brooches with a semi-circular shield date from the 3rd century, and those with triangular shield date from the 4th century (Schmiedehelm 1955, p. 199).

This group of brooches has mainly been found in the northeast part of the tarand cemetery area, with a few coming from central Estonia and the Izhora plateau; therefore, a northeastern origin can be proposed (Fig. 9).

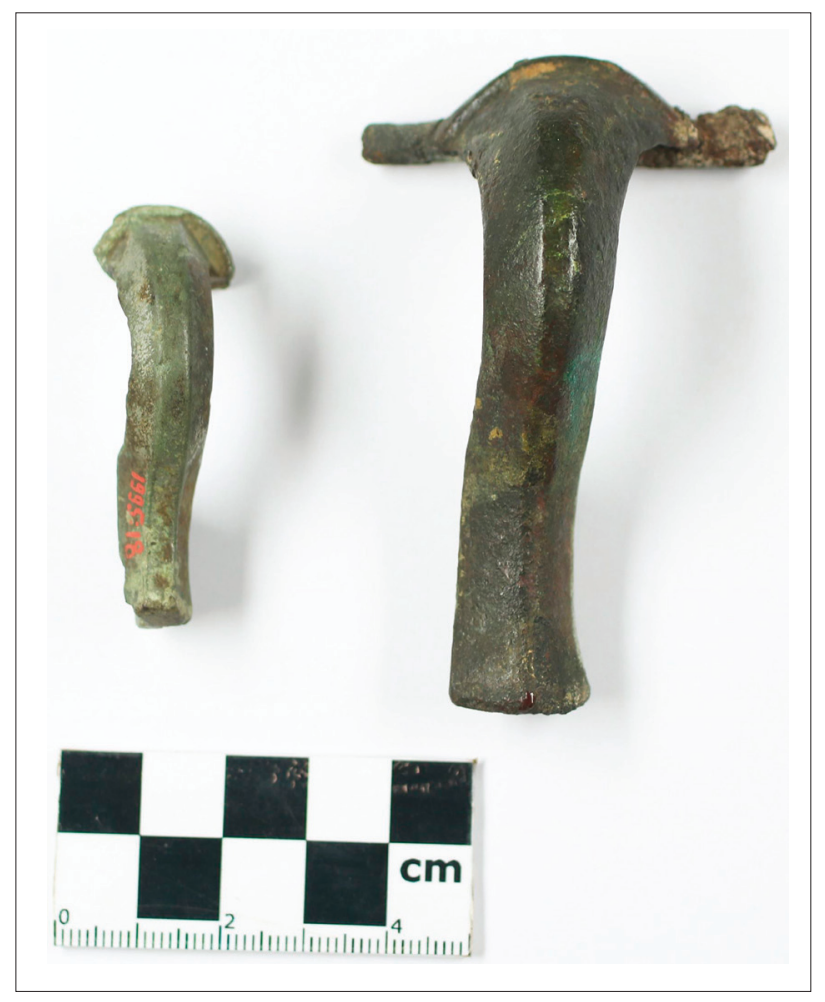

Figure 5. Brooches of local group A (from left: AI 1995: 16, AI 2012.I:9).

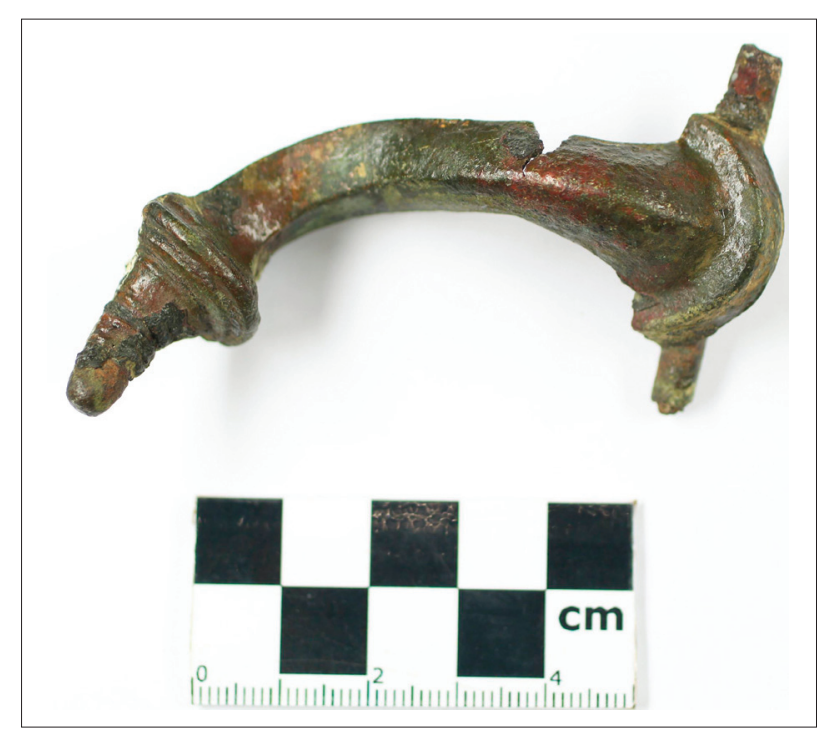

Figure 6. A brooch of local group B (AI 2012.I:11). 


\section{Other head-shield brooches}

There are also some types of head-shield brooches that do not fit these categories, and are represented by only a few specimens. The most numerous of these (6) are similar to Almgren 122 brooches, they have a simple flat bow and a semi-circular shield, which in some cases is decorated. One specimen has silver decoration on it (Catalogue ID-Al 7170:8). This type is also present in Lithuania, where they date from the end of the 1st and to the 2nd century (phases B2 and B2/C1, Michelbertas 1986, p. 113); therefore, those found in the tarand cemetery areas should be dated similarly.

There are some hybrid forms as well. One, for example, has a head-shield and multiple-spring construction, but the foot is shaped as per the foot of an eye-brooch of the Prussian series (Catalogue ID-AI 111:20 for example). Another one also has the same construction, but the bow is similar to that seen on cross-ribbed brooches (AI 3409). One further hybrid has a combination of all the different groups of head-shield brooches: a triangular foot, a knob at the end of the foot, and a tubular variant of the hinge mechanism (Catalogue ID-Al 2496:39). These hybrid versions are found in northeast Estonia, and could be evidence of less controlled local production somewhere in the area.

There is also one imported Roman brooch with an enamelled bow (Catalogue ID-AI 3235:208). This conforms to Heeren and van der Feijst type 56a1 (2017, p. 146), a hinged brooch with a semi-circular head plate, thought to originate in the lower (Dutch) Rhineland area, dated to AD 120-240.

\section{XRF methodology and results}

A Bruker Tracer IIIsd portable X-Ray fluorescence spectrometer (XRF) was used to collect elemental data from the surfaces of the brooches. This device has the advantage of being easily transportable, enabling it to be operated in the archives containing the brooches selected for this paper. The device can be operated by hand, in a 'point and shoot' manner, but instead it was operated on its portable test bench, which allows for a more stable working environment (Potts and West 2008; Shackley 2011; Smit 2012). The machine used for this study was set up as per the manufacturer's standard operating guide. It was fitted with a yellow filter (set to position 1, as per the guide), which is specified for dry atmosphere use and recommended for the high mass elements found in copper-alloy. Trial testing was conducted at $40 \mathrm{kev}-10 \mathrm{um}$, with the signal being found to be stable for 60 -second measurement intervals. These settings remained unchanged throughout the datagathering phase. The measurement outputs were saved as
PDZ files, from which a spectrograph could be produced. These spectrographs were then individually checked for inconsistencies using the manufacturer's S1PXRF software. The manufacturer-supplied copper-alloy calibration $\mathrm{Cu} 1$ was then used to convert the spectra data into quantitative chemical weights (expressed as \%). This calibration allowed for the measurement of the following elements: $\mathrm{Mn}, \mathrm{Fe}, \mathrm{Co}, \mathrm{Ni}, \mathrm{Cu}, \mathrm{Zn}, \mathrm{As}, \mathrm{Pb}, \mathrm{Bi}, \mathrm{Zr}, \mathrm{Nb}, \mathrm{Ag}$, Sn and Sb. A single measurement was subsequently taken on the front face of the bow section of each brooch (Figs. 3-6, 9).

Once the elemental weights were available, the dataset was then subjected to an external normalisation using Microsoft Excel TM. The normalisation step has the effect of correcting the dataset for soil contamination and residues from light elements. Then the main elements present in copper-alloys, copper $(\mathrm{Cu})$, zinc $(\mathrm{Zn})$, tin $(\mathrm{Sn})$ and lead $(\mathrm{Pb})$, were normalised on an iron $(\mathrm{Fe})$ free basis. To aid experimental repeatability, the machine's calibration was compared to that of a Niton XL3t GOLDD XRF analyser (kindly assisted by the Cultural Heritage Agency of the Netherlands), using a shared set of copper-alloy samples (Appendix 2). The results of this analysis are published in Roxburgh and Olli (2019, pp. 217-218). A small variation between the results of both machines was observed, but this variation is insufficient to impede the approach presented in this paper. This research method closely follows the scheme published by Roxburgh et al. (2019), which in turn was inspired by Bayley and Butcher (2004, p. 24), who used ternary diagrams to visually display the three major alloying components, tin (Sn), zinc (Zn) and lead $(\mathrm{Pb})$, as part of their results. This method of visualising the results is particularly useful, as it allows the alloy ratios to be seen as clusters, and therefore to be compared from one group of results to another (Fig. 7). The approach adopted here required non-destructive measurements to be taken on unprepared surfaces, i.e. the brooches were not to be destructively sampled by removing small quantities of metal, nor were small, specially cleaned surface areas allowed that would create a permanent mark on an object's surface. This non-destructive, qualitative approach is consistent with previously published research (Tate 1986; Lutz and Pernicka 1995; Bayley and Butcher 2004; Roxburgh et al. 2016) and that has been proven effective in the basic identification of trends in bulk alloy choice (Tate 1986, p. 23). The results are then analysed interpretively once this stage is achieved, and presented in three-way ternary diagrams, so that relationships between groups and alloy combinations can be easily seen. Those groups made in a zinc-rich alloy, a tin-rich alloy, or a mixture of the two, can then be discussed against brass, bronze or gunmetal-producing traditions. Those groups with a high tin content can also be compared against tin-based surface residues that might be trapped in the corrosion layer. It is uncertain how much these tin residues would influence meas- 


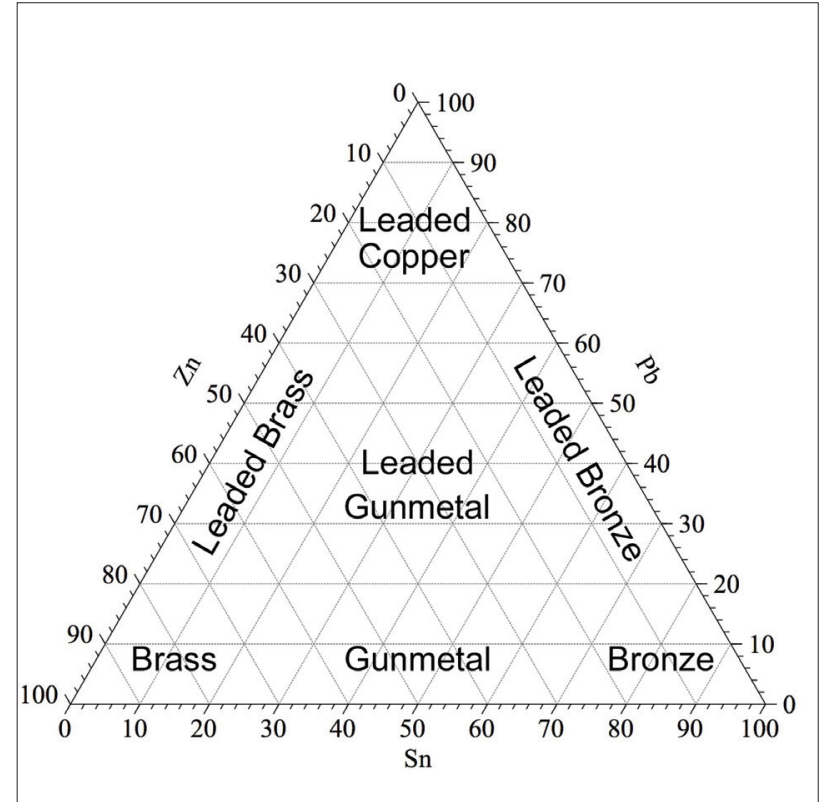

Figure 7. Ternary diagram of Tin $(\mathrm{Sn})$ vs Lead $(\mathrm{Pb})$ vs Zinc $(\mathrm{Zn})$, and the associated compositional classifications.

urements on areas of an object that were not originally surface treated (through tin migration through corrosion over many centuries). However, a tentative suggestion of the main alloy composition could be made based on the presence or absence of zinc, i.e. a completely zinc-free measurement could suggest bronze, but the presence of zinc would suggest brass or gunmetal. Therefore, multiple measurements over the corroded surface of an object were deemed to be ineffective in gaining quantitative information. This is also the limit of effectiveness for XRF employed in this way, mainly due to the variable leeching of copper and zinc in the corrosion process (Roxburgh et al. 2019, p. 67).

A total of 17 brooches were chosen from the larger dataset for the XRF analysis (Table 1). Four were chosen from the triangular foot group, nine from local group A, and a further four were chosen from group B. Although more brooches were included in the typological part of the study, a selection of brooches bearing a very similar morphology to each other was needed, to evaluate the consistency of copper-alloy use in their production. This was especially important when considering the long date assigned to these local head-shield brooches. Style variations within each group could, for example, have been produced many decades or even centuries apart. It was deemed more likely that small numbers of very similar brooches would have been produced in a relatively short time, and therefore could be better assessed for consistency of alloy choice (Figs. 1 and 7). The XRF analysis results are given in the table.

Table 1. Compositional results from XRF. Abbreviation: f. - brooch foot.

\begin{tabular}{|c|c|c|c|c|c|c|c|}
\hline Catalogue ID & Find location & Type & Sn visible & $\mathrm{Cu}$ & $\mathrm{Zn}$ & $\mathrm{Pb}$ & Sn \\
\hline AI 2486:168 & Nurmsi & Triangular f. & yes & 79.7 & 5.6 & 4.0 & 10.7 \\
\hline AI 7170:11 & Lüganuse & Triangular $\mathrm{f}$. & no & 78.3 & 5.1 & 4.1 & 12.4 \\
\hline A $92: 1$ & Kalvi & Triangular $\mathrm{f}$. & no & 91.8 & 5.8 & 0.9 & 1.5 \\
\hline A $313: 2$ & Erra & Triangular $\mathrm{f}$. & no & 77.9 & 6.4 & 7.2 & 8.5 \\
\hline A I3357:346 & Kobratu & Group A & no & 59.5 & 2.4 & 6.5 & 31.5 \\
\hline A $378: 1$ & Lõõla & Group A & no & 66.9 & 5.1 & 2.2 & 25.8 \\
\hline A $377: 2$ & Nurmsi & Group A & yes & 65.9 & 5.9 & 3.7 & 24.5 \\
\hline A $104: 1$ & Arkna & Group A & yes & 86.9 & 0.3 & 2.3 & 10.4 \\
\hline AI 2486:69 & Nurmsi & Group A & yes & 73.7 & 2.8 & 4.4 & 19.1 \\
\hline AI 2486:163 & Nurmsi & Group A & yes & 81.7 & 2.7 & 3.2 & 12.4 \\
\hline A $378: 2$ & Lõõla & Group A & yes & 81.0 & 3.4 & 4.9 & 10.8 \\
\hline A $110: 13$ & Kukruse & Group A & no & 95.4 & 0.5 & 1.9 & 2.2 \\
\hline A $110: 14$ & Kukruse & Group A & no & 89.9 & 2.3 & 2.4 & 5.3 \\
\hline AI 3964:1 & Ridaküla & Group B & no & 72.3 & 11.0 & 7.9 & 8.8 \\
\hline A $92: 2$ & Kalvi & Group B & no & 91.0 & 6.1 & 1.4 & 1.6 \\
\hline A $1091: 1$ & Laanevälja & Group B & no & 78.6 & 6.8 & 5.9 & 8.7 \\
\hline AI 2604:423 & Jäbara & Group B & no & 77.3 & 8.9 & 7.2 & 6.6 \\
\hline
\end{tabular}




\section{Discussion}

\section{Production and decoration}

After considering zinc loss during the corrosion process, the results for the triangular foot group suggest qualitatively that they were made in brass or zinc-rich gunmetal (Fig. 8, upper). One brooch had visible signs of tin on its surface, suggesting that it might have been surface treated to look silver-white in colour. The other triangular foot brooches did not show visible evidence of surface tin, but this might be because it had completely disappeared during the corrosion process. It is possible to suggest, therefore, that some, but maybe not all, triangular foot brooches were surface treated in order to take on a silverwhite colour.

Zinc is also present in local group A brooches (Fig. 8), but these results strongly suggest the presence a systematic surface treatment, using tin as a colorant. This would have resulted in the colour of the brooch being changed from a yellow-gold colour (the body of these brooches again being made of brass or gunmetal) to silver-white. Five of the nine brooches still displayed visible patches of tin, whilst the remaining four had equivalently high tin levels in the XRF results. This suggests that while tin was no longer visible, there was still a large quantity of it trapped in the outer corrosion. This trapped tin is then masking a better understanding of the amount of tin in the brooch itself. It also falsely suggests that the original brooches were made in bronze. The consistency of shape and also of the surface treatment suggests standardised production to a degree.

The local group B brooches had no visible signs of surface treatment. Also, the results are significantly lower in tin than those for the squared-off foot group. This suggests that the results measure the body of these brooches rather than the decayed surface treatment. In this case, they appear to have been produced in brass or a zincrich gunmetal. Regardless of the exact composition, these brooches would have been yellow-gold in colour, unlike those of the squared-off group.

If we consider the chronological progression of these brooch groups formulated by the typological study, the earliest triangular foot brooches were possibly made without a tin surface treatment, implying that their natural yellow-gold colour was the preferred cultural choice. But as time progressed, tin surface treatments became increasingly popular, with silver-white being the preferred colour choice. By the time the squared foot group was common, a silver-white surface treatment was the norm. This fashion then fell out of use with the foot knob group, the surface treatment being discontinued seeing a return to the original yellow-gold colour, perhaps reflective of a change in cultural preference. It is possible, therefore, that these surface measurements reveal a period in time when sil-
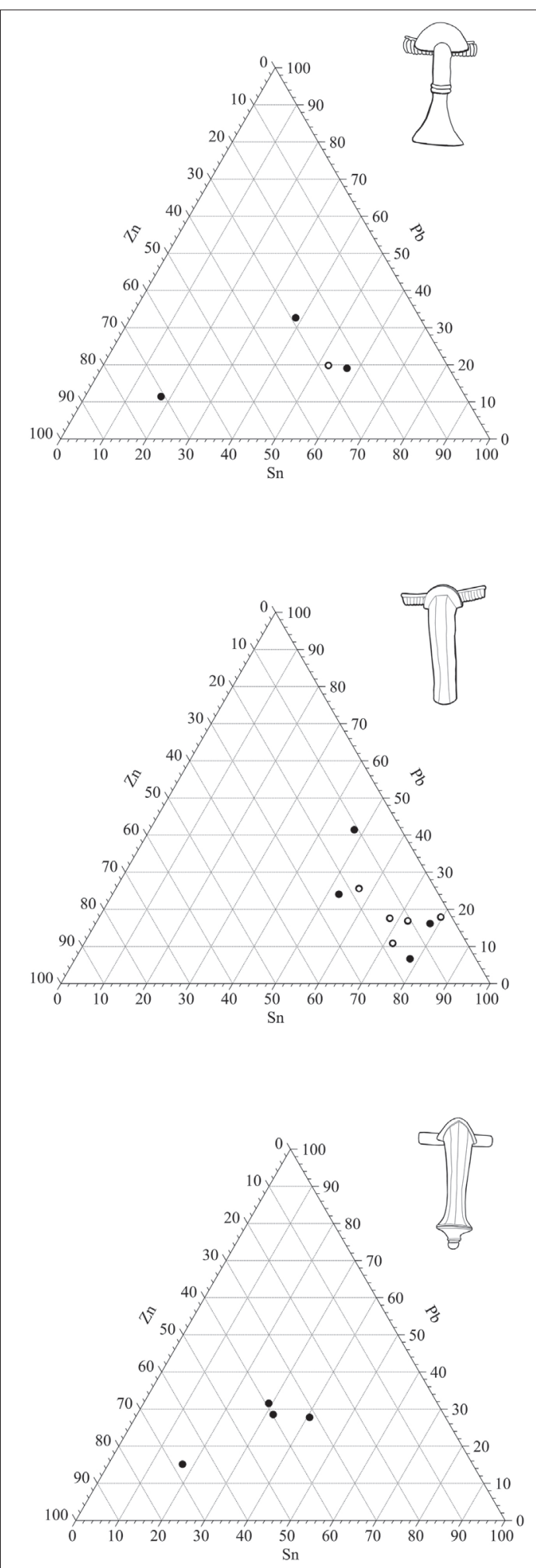

Figure 8. Ternary diagrams: triangular foot (upper), group A (middle), group B (lower). A white dot signifies the visual remains of a tinned surface. 


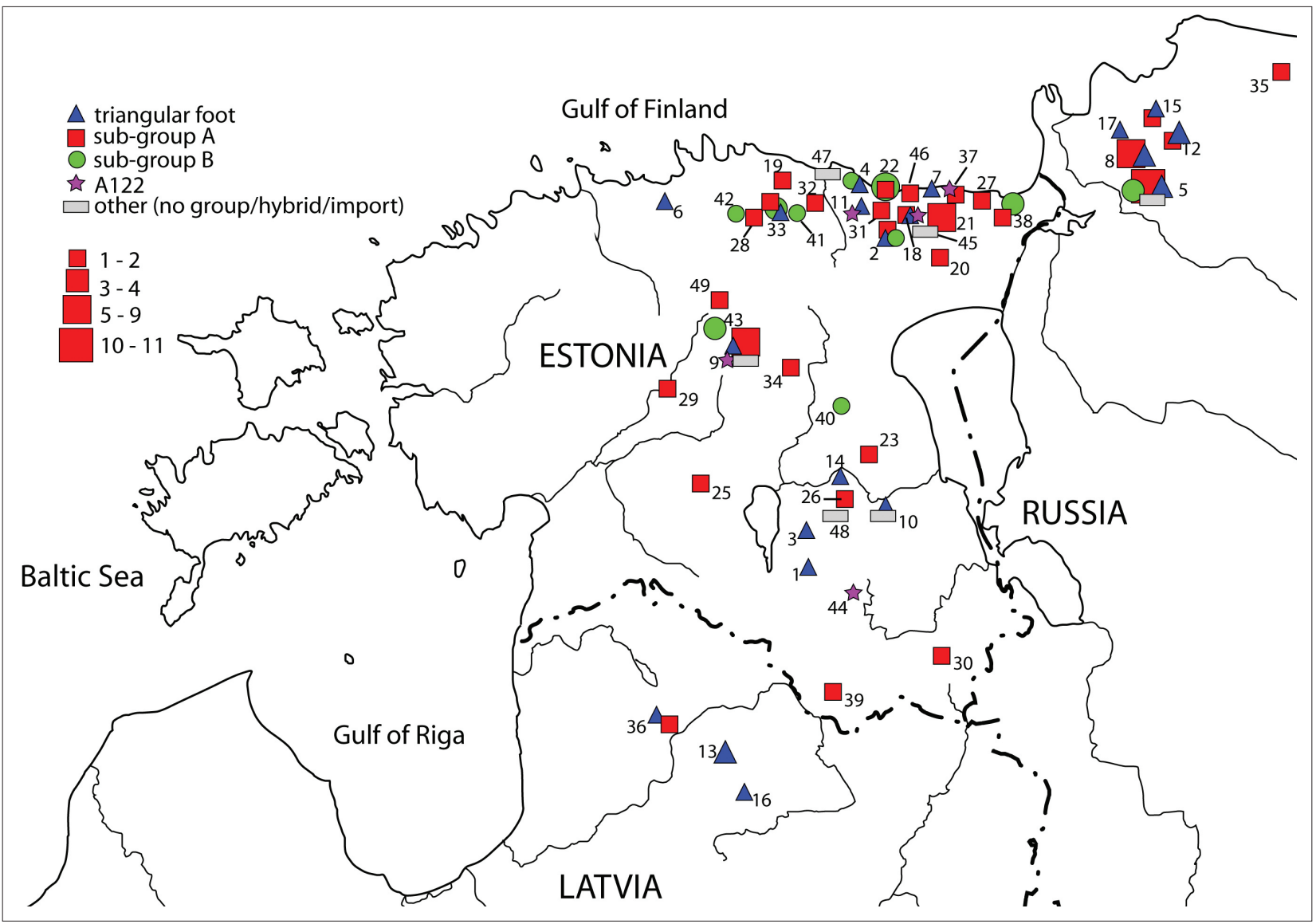

Figure 9. The distribution of head-shield brooches in the tarand cemetery area: 1. Aakre; 2. Erra; 3. Jaagupi; 4. Kalvi; 5. Kerstovo 1; 6. Kiiu; 7. Kohtla; 8. Malli; 9. Nurmsi; 10. Paali; 11. Pada; 12. Ratchino; 13. Slavēka; 14. Truuta; 15. Udosolovo; 16. Vīksnas Kapusils; 17. Voynosolovo; 18. Lüganuse; 19. Arkna; 20. Atsalama; 21. Kukruse; 22. Jäbara; 23. Kobratu; 24. Kullaku (Unipiha); 25. Kuude; 26. Külitse; 27. Künnapõhja; 28. Laanemõisa; 29. Lõõla; 30. Loosi; 31. Purtse-Matka; 32. Rakvere; 33. Tõrma; 34. Ripuka; 35. Ropsha; 36. Saulieži; 37. Toila; 38. Türsamäe; 39. Virunuka; 40. Kärde; 41. Laanevälja; 42. Ridaküla; 43. Tarbja; 44. Kooraste; 45. Järve; 46. Saka; 47. Kunda Hiiemägi; 48. Kambja; 49. Leedu (drawn by Maarja Lillak).

ver-white was the preferred brooch colour rather than the yellow-gold colour of untreated copper-alloy. The chronology for these brooches also matches that for the tinned objects found in Lithuania (Bliujienè and Butkus 2017).

\section{Regionality}

The beginning of the Roman Iron Age was a period when new types of metal items (brooches, bracelets and neckrings) began to spread in the tarand cemetery area (e.g. see Schmiedehelm 1931, p. 399; Rzeszotarska-Nowakiewicz 2010). Head-shield brooches with a triangular foot (Almgren 100) were among the earliest brooches reaching this research area, around the second century AD. They are mainly found in the coastal northeast part of the tarand cemetery area, but also to a lesser degree in southern inland areas (Fig. 9). Their distribution could therefore reflect long-distance connections with other regions: the northeast part of the tarand cemetery area is thought to have had maritime contact with the southeast coastal area of the Baltic Sea, conversely the southern tarand cem- etery areas had their connections through land and river routes with the south (Olli 2019b, pp. 76-82).

The main concentration area of the local groups of headshield brooches (groups A and B) is the northeast part of the tarand cemetery area and central Estonia. Group A is considered to have emerged before group B, however. The earliest example of the former emerged towards the end of the 2nd century, and the latter during the 3rd century. Both groups appear to have lasted until the 4th century. They can be considered a locally produced style, based initially on evidence from the triangular foot group and other non-local types (for example, Almgren 122, Almgren 120). It is plausible that Almgren 100 brooches reached the tarand cemetery area via contact with the southern areas of the Baltic Sea, and for some reason (aesthetic, symbolic, etc) were quite appealing to the peoples living in central and northeast Estonia and on the western slope of the Izhora plateau. They were appealing enough to be recreated locally, but in doing so they gained a touch of local style as well. Over time, therefore, their style, pin construction and composition developed further. Their 


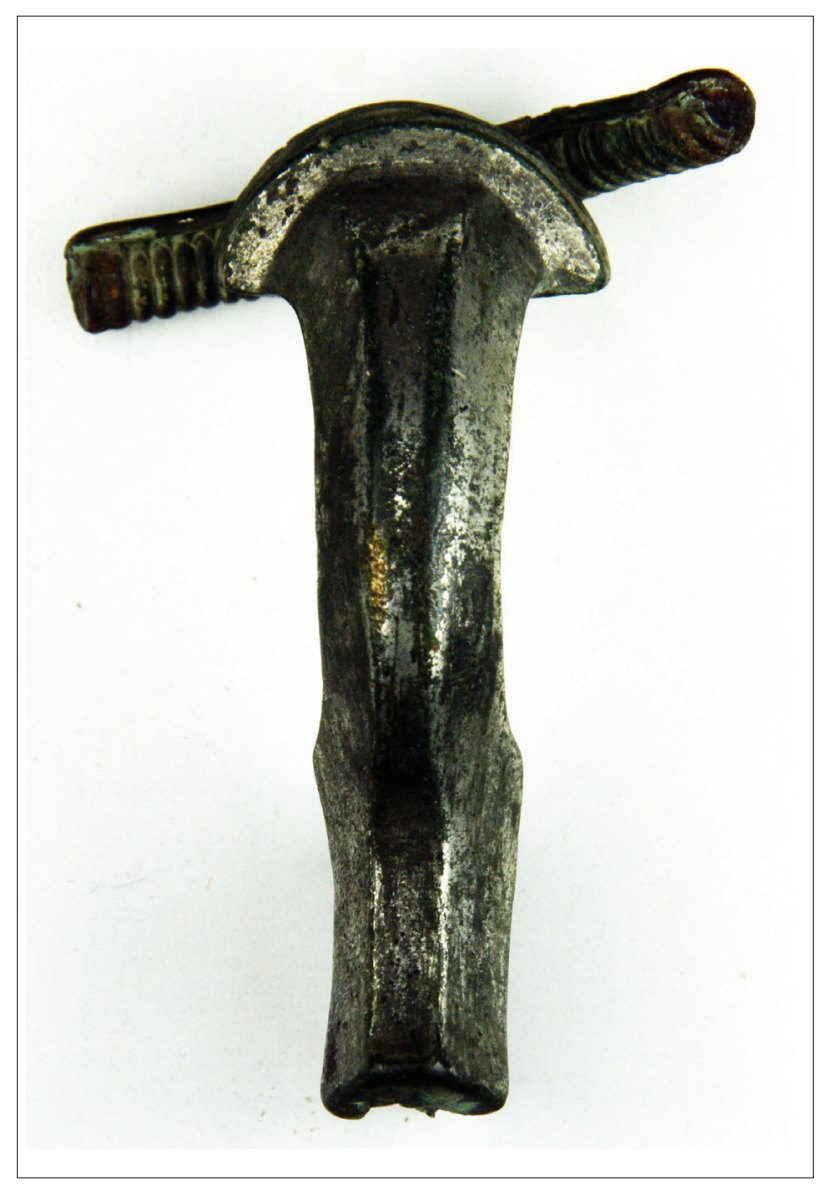

Figure 10. A group A brooch (AI 2486:163), showing the visible remains of surface treatment.

development (i.e. changes in pin construction, size and other morphological elements) can be compared to similar changes in the local eye brooch and cross-ribbed series as well (Roxburgh and Olli 2019; Olli 2019a). Another feature is that all the typological stages of these brooches are present in northeast Estonia (including the hybrid forms). This suggests the existence of one or more production sites for head-shield brooches in this coastal area possibly being exported across to Finland (Kivikoski 1973, p. 29, Abb. 83 and 84).

This distribution area is also quite concentrated. It could imply a local preference for these brooches, perhaps used to display a different social context or membership of a different group, than the other brooch styles in circulation at the time. The social meaning behind the wearing of one brooch form or another could have had many different layers, and was probably dependent on the context they were worn in (Olli 2019b, p. 47). The wearing of a locally distinctive head-shield brooch could, for example, have displayed the regional or social affiliation of the person wearing it. The existence of regional preferences and indicators of regional affiliation have also been proposed for local ornaments in southeast Estonia and northern Latvia, where the presence of local variations of cross-ribbed and disc brooches could also have signalled an affiliation to that region (Olli 2019a). Also, the disc brooches distributed in northeast Estonia versus southeast Estonia/ north Latvia differ noticeably from each other. The presence of two cultural groups has been proposed previously, based on the variation seen in these two areas (Olli and Roxburgh 2018, p. 55). One important variation is that the disc brooches from southeast Estonia and northern Latvia appear to have regularly received tinned surface treatments, whilst the northeast disc brooches (Olli and Roxburgh, 2018, p. 49, group 3 disc brooches) do not. The disc brooches from group 3 date mainly from the 3 rd century, with a small subgroup dating from the 4th century, so they are contemporaneous with the local head-shield groups. Therefore, the local group A brooches, with a regularly tinned outer surface, would be at odds with the colour choice for the disc brooches of the area. If both brooch types were in circulation at the same time, then disc brooches would have been golden-yellow in colour, whilst the squared-off head-shield brooches would have been silvery white in colour. The alternative hypothesis is that the brooches are separated by time, where we see a change in colour preference occurring when a new form is introduced. This would then suggest that the local group $\mathrm{B}$ brooches, being golden yellow in colour, and appearing later than the squared foot group, may have a closer association with the local disc brooches of the same colour. Another alternative is that there was a different social meaning attached to disc and head-shield brooches, allowing one form to display a warm golden-yellow colour, and the other a cool silver-white.

To sum up, it seems plausible overall that group A and B were locally produced. They appear to have developed locally, and played an important visual role in the costume accessories of the people living in the tarand cemeteries area. Additionally, there were other brooch types with head-shields, perhaps non-local in character, which evidence the long-distance contact enjoyed by the people living in this area during the Roman Iron Age.

\section{Conclusion}

The typological part of this study suggests that one of the earliest brooches found in the tarand cemetery area belong to the Almgren 100 group. Most of these brooches have a semi-circular shield on the front part of the bow, a multiple-piece spring, and a triangular foot. The evidence suggests that they first emerged in the 2nd century, being found across most of the area. Subsequently, a local form developed in the northeast part of Estonia, towards the end of the 2 nd century. This local type has a squaredoff foot, a multiple-piece spring construction, and a short semi-circular head-shield; many of them were also tinned, meaning their colour was deliberately changed to a shiny silvery-white. During the 3rd century, a new group of lo- 
cally produced head-shield brooches emerged. They have a hinged mechanism, a knob and a decorative rib at the end of the foot. Many were also very finely crafted.

We propose, therefore, that local craftsmen created groups $\mathrm{A}$ and $\mathrm{B}$. They were originally influenced by the Almgren 100 brooches with head shields, found in the northeast part of the tarand cemetery area. These local brooches probably represented a regional style and aesthetic. We therefore present the hypothesis that these brooches could have played a visual role in connecting the wearer to their affiliated group. A further hypothesis is that they played a differing social role in the identity politics of the society from which they came. Either way, both of these local groups of head-shield brooches coexisted until the end of the 4 th century.

\section{Acknowledgements}

The authors would like to thank Professor Valter Lang (University of Tartu) for his useful feedback on the article, and Ülle Tamla (University of Tallinn) for access to the Archaeological Research Collection of Tallinn University. Marcus A. Roxburgh was supported by the European Regional Development Fund and the Mobilitas Pluss programme (MOBJD576).

\section{Appendix 1 .}

Head-shield brooches in this paper. Head-shield brooches from the Izhora plateau are included, based on M.A.Yushkova (2011;2016). Abbreviation: f. - brooch foot.

\begin{tabular}{|c|c|c|c|c|}
\hline Catalogue ID & Site name & Region & Type & Pin construction \\
\hline AI 2011:3 & Aakre & south-east Est & triangular $\mathrm{f}$. & multiple-piece spring \\
\hline TÜ 2410:283 & Aakre & south-east Est & triangular $\mathrm{f}$. & two lugs \\
\hline A $104: 1$ & Arkna & north-east Est & group A & multiple-piece spring \\
\hline AI 7467:1 & Atsalama & north-east Est & group A & tubular \\
\hline A $313: 3$ & Erra & north-east Est & group $\mathrm{A}$ & multiple-piece spring \\
\hline A $313: 4$ & Erra & north-east Est & group A & multiple-piece spring \\
\hline A $370: 127$ & Erra & north-east Est & group B & tubular \\
\hline A $313: 2$ & Erra & north-east Est & triangular $\mathrm{f}$. & multiple-piece spring \\
\hline AI 1702: 3 & Jaagupi & south-east Est & triangular $\mathrm{f}$. & multiple-piece spring \\
\hline AI 2604:352 & Jäbara & north-east Est & $?$ & tubular? \\
\hline AI 3172:1079 & Jäbara & north-east Est & group A & multiple-piece spring \\
\hline AI 2604:153 & Jäbara & north-east Est & group B & $?$ \\
\hline AI 2604:312 & Jäbara & north-east Est & group B & tubular \\
\hline AI 2604:350 & Jäbara & north-east Est & group B & tubular \\
\hline AI 2604:355 & Jäbara & north-east Est & group B & $?$ \\
\hline AI $2604: 423$ & Jäbara & north-east Est & group B & tubular \\
\hline AI 3172:873 & Jäbara & north-east Est & group B & tubular \\
\hline AI 3172:902 & Jäbara & north-east Est & group B & tubular \\
\hline A $111: 20$ & Järve & north-east Est & hybrid & multiple-piece spring \\
\hline A $111: 55$ & Järve & north-east Est & other & tubular? \\
\hline A $92: 2$ & Kalvi & north-east Est & group B & tubular \\
\hline A $92: 1$ & Kalvi & north-east Est & triangular $\mathrm{f}$. & multiple-piece spring \\
\hline AI 1996:164 & Kambja & south-east Est & import & \\
\hline No 26,14 & Kerstovo 1 & Izhora & other & tubular \\
\hline$?$ & Kerstovo 1 & Izhora & group A & multiple-piece spring \\
\hline No 12,3 & Kerstovo 1 & Izhora & group A & tubular \\
\hline No 13,10 & Kerstovo 1 & Izhora & group A & tubular \\
\hline No 131,8 & Kerstovo 1 & Izhora & group $\mathrm{A}$ & multiple-piece spring \\
\hline No 132,9 & Kerstovo 1 & Izhora & group A & multiple-piece spring \\
\hline No 16,4 & Kerstovo 1 & Izhora & group $\mathrm{A}$ & multiple-piece spring \\
\hline No 23,11 & Kerstovo 1 & Izhora & group A & multiple-piece spring \\
\hline
\end{tabular}




\begin{tabular}{|c|c|c|c|c|}
\hline Catalogue ID & Site name & Region & Type & Pin construction \\
\hline No 25,7 & Kerstovo 1 & Izhora & group $\mathrm{A}$ & tubular \\
\hline No 34,6 & Kerstovo 1 & Izhora & group A & tubular \\
\hline No 43 & Kerstovo 1 & Izhora & group A & $?$ \\
\hline No 5,5 & Kerstovo 1 & Izhora & group A & multiple-piece spring \\
\hline No 11,12 & Kerstovo 1 & Izhora & group B & multiple-piece spring \\
\hline No 148,17 & Kerstovo 1 & Izhora & group B & $?$ \\
\hline No 28 and 16 & Kerstovo 1 & Izhora & group B & $?$ \\
\hline No 14,2 & Kerstovo 1 & Izhora & triangular $\mathrm{f}$. & multiple-piece spring \\
\hline No 17,3 & Kerstovo 1 & Izhora & triangular $\mathrm{f}$. & multiple-piece spring \\
\hline No 31,36 & Kerstovo 1 & Izhora & triangular $\mathrm{f}$. & $?$ \\
\hline A $71: 4$ & Kiiu & north-west Est & triangular $\mathrm{f}$. & tubular \\
\hline AI 3357:346 & Kobratu & north-east Est & group A & tubular \\
\hline AI 7565:1 & Kohtla & north-east Est & triangular $\mathrm{f}$. & multiple-piece spring \\
\hline VM VMT 54:1 & Kooraste & south-east Est & A122? & multiple-piece spring \\
\hline A $110: 11$ & Kukruse & north-east Est & group A & multiple-piece spring \\
\hline A $110: 12$ & Kukruse & north-east Est & group A & multiple-piece spring \\
\hline A $110: 13$ & Kukruse & north-east Est & group A & multiple-piece spring \\
\hline A $110: 14$ & Kukruse & north-east Est & group A & multiple-piece spring \\
\hline A $110: 15$ & Kukruse & north-east Est & group A & tubular \\
\hline AI $1995: 18$ & Kullaku (Unipiha) & south-east Est & group $\mathrm{A}$ & multiple-piece spring \\
\hline AI 3409 & Kunda Hiiemägi & north-east Est & hybrid & multiple-piece spring \\
\hline VM VMT 11:38 & Kuude & south-east Est & group A & multiple-piece spring \\
\hline AI 1918:1 & Kärde & central Est & group B & tubular \\
\hline TÜ 433:7 & Külitse & south-east Est & group A & multiple-piece spring \\
\hline AI 3791:1 & Künnapõhja & north-east Est & group $\mathrm{A}$ & multiple-piece spring \\
\hline AI 3447:1 & Laanemõisa & north-east Est & group A & multiple-piece spring \\
\hline AI 3447:2 & Laanemõisa & north-east Est & group A & tubular \\
\hline A $1091: 1$ & Laanevälja & north-east Est & group B & tubular? \\
\hline A $1091: 4$ & Laanevälja & north-east Est & group B & $?$ \\
\hline A $376: 26$ & Leedu & central Est & group A & multiple-piece spring \\
\hline A $376: 27$ & Leedu & central Est & group A & multiple-piece spring \\
\hline AI 4375: 74 & Loosi & south-east Est & group A & tubular \\
\hline A 378:1 & Lõõla & central Est & group A & multiple-piece spring \\
\hline A $378: 2$ & Lõõla & central Est & group A & tubular? \\
\hline AI 7170:8 & Lüganuse & north-east Est & A122 & multiple-piece spring \\
\hline AI $7170: 13$ & Lüganuse & north-east Est & group A & $?$ \\
\hline AI 7170:11 & Lüganuse & north-east Est & triangular $\mathrm{f}$. & multiple-piece spring \\
\hline$?$ & Malli & Izhora & group A & tubular \\
\hline$?$ & Malli & Izhora & group $\mathrm{A}$ & multiple-piece spring \\
\hline$?$ & Malli & Izhora & group $\mathrm{A}$ & multiple-piece spring \\
\hline$?$ & Malli & Izhora & group A & \\
\hline$?$ & Malli & Izhora & group A & \\
\hline$?$ & Malli & Izhora & group A & \\
\hline$?$ & Malli & Izhora & triangular $\mathrm{f}$. & multiple-piece spring \\
\hline AI 2486:135 & Nurmsi & central Est & A122 & multiple-piece spring \\
\hline AI 2486:90 & Nurmsi & central Est & A122 & multiple-piece spring \\
\hline AI 2486:125 & Nurmsi & central Est & import? & multiple-piece spring \\
\hline A $377: 1$ & Nurmsi & central Est & group A & tubular \\
\hline A $377: 2$ & Nurmsi & central Est & group A & tubular \\
\hline
\end{tabular}




\begin{tabular}{|c|c|c|c|c|}
\hline Catalogue ID & Site name & Region & Type & Pin construction \\
\hline AI 2486:124 & Nurmsi & central Est & group A & tubular \\
\hline AI $2486: 163$ & Nurmsi & central Est & group $\mathrm{A}$ & multiple-piece spring \\
\hline AI 2486:69 & Nurmsi & central Est & group A & multiple-piece spring \\
\hline AI $2486: 168$ & Nurmsi & central Est & triangular f. & multiple-piece spring \\
\hline AI 2486:64 & Nurmsi & central Est & triangular f. & multiple-piece spring \\
\hline AI 3235:208 & Paali & south-east Est & import & two lugs \\
\hline AI 3235:207 & Paali & south-east Est & triangular f. & two lugs \\
\hline AI 2655:19 & Pada & north-east Est & A122 & tubular \\
\hline AI 2655:44 & Pada & north-east Est & group $\mathrm{A} / \mathrm{B}$ & tubular \\
\hline AI $2655: 10$ & Pada & north-east Est & triangular $\mathrm{f}$. & multiple-piece spring \\
\hline AI 3735:3 & Purtse-Matka & north-east Est & group A & tubular \\
\hline AI 3183: 5 & Rakvere & north-east Est & group $\mathrm{A}$ & $?$ \\
\hline$?$ & Ratchino & Izhora & group A & tubular \\
\hline$?$ & Ratchino & Izhora & triangular $\mathrm{f}$. & $?$ \\
\hline$?$ & Ratchino & Izhora & triangular $\mathrm{ft}$, & $?$ \\
\hline$?$ & Ratchino & Izhora & triangular $\mathrm{ft}$, & tubular \\
\hline AI2488:156 & Tõrma & north-east Est & group B & \\
\hline AI2488:157 & Tõrma & north-east Est & group B & \\
\hline AI2496:2 & Tõrma & north-east Est & group B & \\
\hline AI2496:39 & Tõrma & north-east Est & group B & \\
\hline AI 3964:1 & Ridaküla & north-east Est & group $B$ & tubular \\
\hline AI 616 & Ripuka & north-east Est & group A & tubular \\
\hline$?$ & Ropsha & Izhora & group A & \\
\hline AI 2508:4 & Saka & north-east Est & group $\mathrm{A}$ & double spring \\
\hline A 3551 & Saulieži & Latvia & group $\mathrm{A}$ & $?$ \\
\hline A 3552 & Saulieži & Latvia & triangular $\mathrm{f}$. & tubular \\
\hline AI 1195: 103 & Slavēka & Latvia & triangular f. & multiple-piece spring \\
\hline AI 1195: 95 & Slavēka & Latvia & triangular f. & multiple-piece spring \\
\hline AI 1195: 97 & Slavēka & Latvia & triangular f. & multiple-piece spring \\
\hline PM 848 A44:385 & Tarbja (Kalamehe) & central Est & group B & tubular \\
\hline PM 848 A44:386 & Tarbja (Kalamehe) & central Est & group B & tubular \\
\hline PM 2 A2:7 & Tarbja (Miku) & central Est & group B & tubular \\
\hline RM 584 A3:34 & Toila & north-east Est & A122 & multiple-piece spring \\
\hline RM 584 A3:218 & Toila & north-east Est & group A & multiple-piece spring \\
\hline RM 616 A4:30 & Toila & north-east Est & group A & $?$ \\
\hline AI 1993:8 & Truuta & south-east Est & triangular $\mathrm{f}$. & multiple-piece spring \\
\hline AI 2496:57 & Tõrma & north-east Est & group A & multiple-piece spring \\
\hline AI 2496:73 & Tõrma & north-east Est & group A & multiple-piece spring \\
\hline AI 2012I:9 & Türsamäe & north-east Est & group $\mathrm{A}$ & tubular \\
\hline AI 2012I:10 & Türsamäe & north-east Est & group B & tubular \\
\hline AI 2012I:11 & Türsamäe & north-east Est & group B & tubular \\
\hline AI 2012I:11a,b & Türsamäe & north-east Est & group B & tubular \\
\hline AI 2012II:18 & Türsamäe & north-east Est & group B & tubular \\
\hline$?$ & Udosolovo & Izhora & group A & multiple-piece spring \\
\hline$?$ & Udosolovo & Izhora & triangular $\mathrm{f}$. & multiple-piece spring \\
\hline AI 1239:3 & Vīksnas Kapusils & Latvia & triangular f. & multiple-piece spring \\
\hline AI 4262: 213 & Virunuka & south-east Est & group A & tubular \\
\hline$?$ & Voynosolovo & Izhora & triangular $\mathrm{f}$. & $?$ \\
\hline
\end{tabular}


Appendix 2 .

\section{Comparison of Bruker versus Niton analyser}

\begin{tabular}{|l|l|l|l|l|}
\hline Sample & Cu (av.) & Sn (av.) & Zn (av.) & Pb(av.) \\
\hline \multicolumn{5}{|c|}{ Niton analyser } \\
\hline Bronze & 79.0 & 15.0 & 0.0 & 5.5 \\
\hline Brass & 84.0 & 0.0 & 12.0 & 4.5 \\
\hline Gunmetal (+Sn) & 80.5 & 10.0 & 4.5 & 5.5 \\
\hline Gunmetal (+Zn) & 79.5 & 6.0 & 8.0 & 6.5 \\
\hline \multicolumn{5}{|c|}{ Bruker analyser } \\
\hline Bronze & 76.0 & 16.5 & 0.0 & 7.5 \\
\hline Brass & 82.5 & 0.5 & 12.0 & 5.5 \\
\hline Gunmetal (+Sn) & 79.0 & 10.0 & 12.0 & 6.5 \\
\hline Gunmetal (+Zn) & 79.5 & 5.5 & 8.0 & 7.0 \\
\hline
\end{tabular}

\section{References}

Almgren, O., 1897. Studien über nordeuropäische Fibelformen der ersten nachchristlichen Jahrhunderte mit Berücksichtigung der provinzialrömischen und südrussischen Formen. Stockholm: Druck von I. Hæggström.

Bayley, J., Butcher. S., 2004. Roman Brooches in Britain: A Technological and Typological Study based on the Richborough collection. London: The society of antiquaries of London.

Banytė-Rowell, R., Bitner-Wróblewska, A., 2005. From Aestii to Esti. Connections between the Western Lithuanian Group and the area of distribution of tarand-graves. In: V. Lang, ed. Interarchaeologia, 1, Culture and Material Culture. Papers from the first seminar of the Baltic archaeologists (BASE), held at the University of Tartu, Estonia, October 17th-19th, 2003. TartuRiga-Vilnius: printed in Estonia by Pakett Press, Tallinn, pp. 105-120.

Bliujienè, A., 2013. Romeniškasis ir tautu kraustymosi laikotarpiai. In: Lietuvos Archeologija, Vol. III. Klaipeda: Klaipeda Universiteto leidykla.

Bliujiené, A., Butkus, D., 2017. Heralds of the Late Roman Period or Some Remarks about the Balt Fibulae Type Almgren 133. In: J. Andrzejowski, C. von Carnap-Bornheim, A. Cieśliński, B. Kontny eds. Orbis Barbarorum - Orbis Barbarorum. Studia and Archaeologiam Germanorum et Baltorum Temporibus Imperii Romani Pertinentia Adalberto Nowakowski Dedicata. Monumenta Archaeologica Barbarica, Series Gemina, t. VI. Warszawa-Schleswig, pp. 97-111.

Chiavari, C., Rahmouni, K., Takenouti, H., Joiret, S., Vermaut, P., Robbiola, L., 2007. Composition and electrochemical properties of natural patinas of outdoor bronze monuments. Electrochimica Acta, 52 (27), 7760-7769.

Craddock, P.T., 1988. Copper Alloys of the Hellenistic and Roman World: New Analyses and Old Authors. - Aspects of Ancient Mining and Metallurgy. In: J.E. Jones, ed. Acta of a British School at Athens Centenary Conference at Bangor (1986). Bangor: University College of Wales, pp. 55-65.

Dungworth, D. 1997., Roman Copper Alloys: Analysis of Artefacts from Northern Britain. Journal of Archaeological Science, 24 (10), 901-910.

Gigante, G.E., Ricciardi, P., Ridülfi, S., 2005. Areas and limits of employment of portable EDXRF equipment for in situ investigations. Archéo Sciences. Revue d'Archéométrie, 29, 51-59.

Göbel, F., 1842. Ueber den Einfluss der Chemie auf die Ermittelung der Völker der Vorzeit, oder, Resultate der chemischen
Untersuchung metallischer Alterthümer insbesondere der in den Ostseegouvernements vorkommenden, Behufs der Ermittelung der Völker, von welchen sie abstammen. Erlangen: Ferdinand Enke.

Hausmann, R., 1896. Grabfunde aus Estland: eine archäologische Studie. Reval: Der Estländischen Literärischen Gesellschaft.

Heeren, S. and van der Feijst, L., 2017. Prehistorische, Romeinse en middeleeuwse fibulae uit de Lage Landen. Beschrijving, analyse en interpretatie van een archeologische vondstcategorie. Amersfoort: Eigen Beheer.

Yushkova, M.A., 2011. Ėpokha bronzy i ranniŭ zheleznyĭ vek na Severo-Zapade Rossii. (The Bronze Age and the Early Iron Age in Northwest Russia). Dissertatsiia na soiskanie uchenoi stepeni kandidata istoricheskikh nauk. Sant-Petersburg.

Yushkova, M.A., 2016. A New Group of Tarand Graves in the South-Western Part of Leningrad Oblast. Iskos, 21, 143-159.

Keskitalo, O., 1979. Suomen nuoremman roomalaisen rautakauden löydot. Helsingin yliopiston Arkeologian laitos, Moniste, 20. Helsinki: Helsingin yliopiston arkeologin laitos.

Kivikoski, E., 1973. Die Eisenzeit Finnlands. Bildwerk und Text. Helsinki: Werner Söderström Osakeyhtiö, Porvoo.

LA 1974. Apals, J., Atgāzis, M., Daiga, J., Deņisova, R., Graudonis, J., Loze, I., Mugurēvičs, Ē., Stuba, Ā., Snore, E., Zagorskiš, F. \& Zariņa, A. Latvijas PSR arheologija. Zinātne, Rīga.

Lang, V., 1996. Muistne Rävala. Muistised, kronoloogia ja maaviljelusliku asustuse kujunemine Loode-Eestis, eriti Pirita jõe alamjooksu piirkonnas, I-II. Muinasaja teadus, 4. Tallinn: Eesti Teaduste Akadeemia Ajaloo Instituut.

Lang, V., 2007. The Bronze and Early Iron Ages in Estonia. Estonian Archaeology, Vol. 3. Tartu: Tartu University Press.

Lang, V., 2018. Läänemeresoome tulemised. Muinasaja teadus, 28. Tartu: Tartu University Press.

Laul, S., 2001. Rauaaja kultuuri kujunemine Eesti kaguosas (500 e. $\mathrm{Kr}-500$ p. Kr). Muinasaja teadus, 9 / Oppetatud Eesti Seltsi kirjad, 7. Tallinn: Ajaloo Instituut.

Lutz, J., Pernicka, E., 1995. Energy Dispersive X-Ray Fluorescence Analysis of Ancient Copper Alloys: Empirical Values for Precision and Accuracy. Archaeometry, 38 (2), 313-323.

Martinón-Torres, M., LI, X.J., Bevan, A., Xia, Y., Zhao, K., Rehren, T., 2014. Forty Thousand Arms for a Single Emperor: From Chemical Data to the Labor Organization Behind the Bronze Arrows of the Terracotta Army. Journal of Archaeological Method and Theory, 21 (3), 534-562.

Michelbertas, M., 1986. Senasis geležies amžius Lietuvoje. I-IV amžius. Vilnius: Mokslas.

Moora, H., 1923. Über die Augenfibel in Est- und Lettland. Sitzungsberichte der Gelehrten Estnischen Gesellschaft, 1922, 109-123.

Moora, H., 1938. Die Eisenzeit in Lettland bis etwa 500 n. Chr., II. Teil: Analyse. Õpetatud Eesti Seltsi Toimetused, XXIX. Tartu: Õpetatud Eesti Selts.

Nowakowski, W., 2013. Masuren in der Römischen Kaiserzeit. Auswertung der Archivalien aus dem Nachlass von Herbert Jankuhn. Studien zur Siedlungsgeschichte und Archäologie der Ostseegebiete, 12. Neumünster: Wachholtz Verlag.

Olli, M., Roxburgh, M. A., 2018. Disc brooches of the Roman Iron Age from the tarand cemeteries of Estonia and north Latvia. Lietuvos archeologija, 44, 43-74.

Olli, M., 2019a. Regions and communication in south-east Estonia and north Latvia in the third and fourth centuries based on local ornaments. Estonian Journal of Archaeology, 23 (2), 75-102.

Olli, M., 2019b. From individuality to regionality in the distribution area of tarand cemeteries in the Roman Iron Age. Dissertationes archaeologiae Universitatis Tartuensis, 9. Tartu: Tartu Ülikooli Kirjastus. 
Potts, P.J., West, M. (eds.), 2008. Portable X-ray Fluorescence Spectrometry: Capabilities for in Situ Analysis. Cambridge: RSC Publishing.

Robbiola, L., Blengino, J.M., Fiaud, C., 1998. Morphology and mechanisms of formation of natural patinas on archaeological $\mathrm{Cu}$-Sn alloys. Corrosion Science, 40 (12), 2083-2111.

Roxburgh, M., Heeren, S., Huisman, H., van Os, B., 2016. Early Roman copper-alloy brooch production: a compositional analysis of 400 brooches from Germania Inferior. Journal of Roman Archaeology, 29, 411-421.

Roxburgh, A., Olli, M., 2019. Eyes to the North: a compositional analysis of copper-alloy eye brooches in the Eastern Baltic, produced during the Roman Iron Age. Germania, 96 (2018), 601-626.

Roxburgh, M., Heeren, S., Huisman, H., van Os, B., 2019. A Non-destructive survey of early Roman copper-alloy brooches using portable X-ray Fluorescence Spectrometry. Archaeometry, 61 (1), 55-69.

Rzeszotarska-Nowakiewicz, A., 2010. Neckrings with trumpetshaped terminals (mit Trompetenenden). - some remarks on traces of contacts in the Baltic basin during the Early Roman Period. In: U. Lund Hansen, A. Bitner-Wróblewska, eds. Worlds Apart? Contacts across the Baltic Sea in the Iron Age. Network Denmark Poland, 2005-2008. Warszawa, København: Państwowe Muzeum Archeologiczne, Det Kongelige Nordiske Oldskriftselskab, 315-336.

Salo, U., 1968. Die Fruhrömische Zeit in Finnland. Suomen Muinaismuistoyhdistyksen Aikakauskirja, 67. Helsinki: Suomen Muinaismuistoyhdistys.

Schmiedehelm, M., 1923. Beiträgezu der sogenannten gotischen Frage im Baltikum. Sitzungsberichte der Gelehrten Estnischen Gesellschaft, 1922, 76-108.

Schmiedehelm, M., 1931. Über die Beziehungen zwischen dem Weichselgebiet und Estland zur römischen Eisenzeit. Congressus Secundus Archaeologorum Balticorum Rīgae, 19.-23. VIII 1930. Riga, pp. 395-405.

Schmiedehelm, M., 1955 Arkheologicheskie pamiatniki perioda razlozheniia rodogogo stroia na severo-vostoke Estonii. (The archaeological monuments of north-east Estonia during the decline of the tribal system. 5th century BC to 5th century AD). Tallinn: Таллин: Ėstonskoe gosudarstvennoe izdate'stvo.

Shackley, M.S., ed., 2011. X-Ray Fluorescence Spectrometry (XRF) in Geoarchaeology. London: Springer.

Shugar, A.N., Mass, J.L. (eds.), 2012. Handheld XRF for Art and Archaeology. Studies in Archaeological Sciences, 3. Leuven: Leuven University Press.

Smith, D., 2012. Handheld X-ray fluorescence analysis of Renaissance bronzes: practical approaches to quantification and acquisition. In: A.N. Shugar, J.L. Mass, eds. Handheld XRF for Art and Archaeology. Studies in Archaeological Sciences, 3. Leuven: Leuven University Press, pp. 37-74.

Smythe, J. A., 1938. Roman objects of copper and iron from the north of England. Proceedings of the University of Durham Philosophical Society, 9, 382-405.

Szymański, P., 2005. Mikroregion osadniczy $z$ okresu wpływów rzymskich $w$ rejonie jeziora Salęt na Pojezierzu Mazurskim. Swiatowit. Prehistory and Middle Ages, 10. Warszawa: Instytut Archeologii Uniwersytetu Warszawskiego.

Tate, J., 1986. Some problems in analysing museum material by non-destructive surface sensitive techniques. Nuclear Instruments and Methods in Physics Research Section B: Beam Interactions with Materials and Atoms, 14 (1), 20-23.

Unglick, H., 1991. Structure, composition and technology of late Roman copper alloy artifacts from the Canadian excavations at Carthage. Archaeomaterials, 5, 91-110.
Van Thienen, V., Lycke, S., 2017. From commodity to singularity: The production of crossbow brooches and the rise of the late Roman military elite. Journal of Archaeological Science, 82, 50-61.

Vasks, A., 2001. Agrais dzelzs laikmets. 1.-400. g. In: $\bar{E}$. Mugurēvičs, A. Vasks, eds. Latvijas senākā vēsture. Rīga: Latvijas vēstures institūta apgāds, 186-231.

Vassar, A., 1943. Nurmsi kivikalme Eestis ja tarandkalmete areng. Thesis $(\mathrm{PhD})$. University of Tartu.

ROMĖNIŠKOJO GELEŽIES

AMŽIAUS SKYDELINÉS SEGÉS

IŠ RYTÜ BALTIJOS REGIONO

TARANDŲ KAPINYNŲ

\section{MAARJA LILLAK, MARCUS A. ROXBURGH}

\section{Santrauka}

Tarandų kapinynų paplitimo teritorijoje randamos skydelinès segès pirmiausia atpažǐstamos pagal jų skiriamąji bruožą - lankelio viršuje esantị masyvų skydelị ir trikampę ar kiek platėjančią stačiakampę kojelę (1-6 pav.). Tokia segių forma jas sieja su Almgreno V grupès, 100 tipo segèmis, paplitusiomis šiauriniame Barbaricum regione. Segès datuojamos romėniškuoju geležies amžiumi ir yra vienos iš ankstyviausių segių, randamų tarandų kapinynų paplitimo teritorijoje. Almgreno $\mathrm{V}$ grupès segių taip pat randama pietrytiniame Baltijos jūros regione.

Šis straipsnis skirtas skydelinèms segèms, paplitusioms tarandų kapinynuose Estijoje, Latvijoje ir žemèse ị vakarus nuo Ižoros plokštikalnès (pietvakarinė Leningrado srities dalis). Straipsnio tikslas - apibūdinti šių skydelinių segių raidą, derinant tipologini, metalo elementinès sudèties ir chronologinị tyrimą. Autoriai ịvairius morfologinius skydelinių segių raidos aspektus nagrinejja tiek regioniniame kontekste, tiek juos lygina su panašiais pokyčiais, vykusiais kitur, kad būtų galima geriau suprasti žmonių, gyvenusių tarandu kapinynų paplitimo teritorijoje, kontaktų pobūdị. Be to, šių segių vario lydinio kompozicija buvo tiriama nedestrukciniu rentgeno fluorescencijos spektrometrijos (XFR) metodu nešiojamuoju spektrometru. Vario lydinių elementinès sudèties tyrimai padès geriau suprasti senovès amatininkų metalo pasirinkimą šių segių gamybai.

Šiame darbe remiamasi apie 140 skydelinių segių, žinomų iš aptariamos tarandų kapinynų teritorijos (1; 9 pav.). 129 segès iš 140 buvo ittrauktos aptariant tipologinę šio tipo segių raidos analizę. Daugelis aptariamų segių liemenèlio viršuje turi masyvų pusapvalio pavidalo skydelį, aši ir trikampiškai užbaigtą kojelę (3, kairèje; 4 pav.). Archeologinè medžiaga rodo, kad segès atsirado II a. ir paplito 
visoje tarandu kapinynų teritorijoje. Vèliau, II a. pabaigoje, Šiaurès rytų Estijoje atsiranda vietinè šių segių forma. Vietinė A grupe turi neaukštą skydeli lankelio viršuje, aši ir platejjančią stačiakampę kojelę. Daugelio šių segių paviršius alavuotas, o tai reiškia, kad jų spalva sąmoningai pakeista į blizgančią sidabriškai baltą (3, viduryje; $5 ; 10$ pav.). III a. atsirado nauja vietinių skydelinių segių B grupè (3, dešinèje; 6 pav.). Šios grupès segių užsegimas - šarnyrinis ir turi neaukštą volelị kojelès gale.

XRF metodu buvo ištirta 17 skydelinių segių vario lydinio elementinè sudètis (1 lentelè). Remiantis atliktais spektrometriniais tyrimais, ankstyviausios skydelinès segès su trikampe kojele galejo būti nedengtos alavo danga, o tai reiškia, kad natūrali geltona aukso spalva buvo kultūrinis reiškinys. Tačiau laikui bėgant segių paviršiaus dengimas alavu populiarejo, o balta sidabrinè spalva tapo pageidautina (7; 8 pav.).

Tuo tarpu A grupès segès paprastai buvo dengiamos sidabriškai balta alavo danga. Segių dengimas alavo danga išejo iš mados, nustojus gaminti B grupès seges; matyti grịžimas ị natūralią vario lydinio aukso spalvą. Tikètina, kad šis procesas atspindi pasikeitusias kultūrines nuostatas.

Straipsnio autoriai kelia prielaidą, kad vietiniai amatininkai sukūrè skydelinių segių A ir B grupes kaip Almgreno 100 tipo segiu prototipus (9 pav.). Šios vietinès segès tikriausiai atspindejo regionini stilių ir estetiką. Todèl, autorių manymu, šios segès jų nešiotojus galèjo vizualiai sieti su socialine grupe ir rodyti jų tapatybę. Straipsnyje aptariamos skydelinès segès tarandų kapinynų srityje egzistavo iki IV a. pabaigos. 